\title{
Embryonic development and larval stages of Steindachneridion parahybae (Siluriformes: Pimelodidae) - implications for the conservation and rearing of this endangered Neotropical species
}

\author{
Renato M. Honji ${ }^{1}$, Carlos E. Tolussi ${ }^{1}$, Paulo H. Mello ${ }^{1}$, Danilo Caneppele ${ }^{2}$ \\ and Renata G. Moreira ${ }^{1}$
}

Steindachneridion parahybae is a freshwater catfish endemic to the Paraíba do Sul River and is classified as an endangered Neotropical species. An increasing number of conservation biologists are incorporating morphological and physiological research data to help conservation managers in rescue these endangered species. This study investigated the embryonic and larval development of $S$. parahybae in captivity, with emphasis in major events during the ontogeny of S. parahybae. Broodstocks were artificially induced to reproduce, and the extrusion occurred 200-255 degree-hours after hormonal induction at $24^{\circ} \mathrm{C}$. Larval ontogeny was evaluated every 10 minutes under microscopic/stereomicroscopic using fresh eggs samples. The main embryogenic development stages were identified: zygote, cleavage, including the morula, blastula, gastrula phase, organogenesis, and hatching. The extruded oocytes showed an average diameter of $1.10 \pm 0.10 \mathrm{~mm}$, and after fertilization and hydration of eggs, the average diameter of eggs increased to about $1.90 \pm 0.60 \mathrm{~mm}$, characterized by a large perivitelline space that persisted up to embryo development, the double chorion, and the poles (animal and vegetative). Cell division started about 2 minutes after fertilization (AF), resulting in 2, 4, 8 ( $4 \times 2$ arrangement of cells), $16(4 \times 4), 32(4 \times 8)$ and $64(2 \times 4 \times 8)$ cells. Furthermore, the blastula and gastrula stages followed after these cells divisions. The closed blastopore occurred at $11 \mathrm{~h} 20$ min AF; following the development, the organogenetic stages were identified and subdivided respectively in: early segmentation phase and late segmentation phase. In the early segmentation phase, there was the establishment of the embryonic axis, and it was possible to distinguish between the cephalic and caudal regions; somites, and the optic vesicles developed about $20 \mathrm{~h}$ AF. Total hatching occurred at $54 \mathrm{~h} \mathrm{AF}$, and the larvae average length was $4.30 \pm 0.70 \mathrm{~mm}$. Gradual yolk sac reduction was observed during the first two days of larval development. The first feeding occurred at the end of the second day. During the larval phase, cannibalism, heterogeneous larval growth and photophobia were also observed. This information will be important in improving the artificial reproduction protocols of S. parahybae in controlled breeding programs.

Steindachneridion parahybae é um bagre de água doce, endêmico do rio Paraíba do Sul e é classificado como espécie neotropical ameaçada. Um número crescente de biólogos conservacionistas estão incorporando dados de pesquisas morfológicas e fisiológicas para ajudar os gestores de conservação no resgate destas espécies ameaçadas de extinção. Este estudo investigou o desenvolvimento embrionário e larval de $S$. parahybae em cativeiro, com ênfase nos principais eventos durante a ontogenia de $S$. parahybae. Reprodutores foram artificialmente induzidos à reprodução e a extrusão ocorreu com 200-255 horas-graus após a indução hormonal a $24^{\circ} \mathrm{C}$. A ontogenia larval foi avaliada a cada 10 minutos sob microscópio/ estereomicroscópio, utilizando-se amostras de ovos recém coletados. Os principais estágios de desenvolvimento embrionário foram identificados: zigoto, clivagem, incluindo as fases, mórula, blástula e gástrula, organogênese e eclosão. Os ovócitos extrusados apresentaram uma média de diâmetro de 1,10 $0,10 \mathrm{~mm}$ e depois da fertilização e hidratação dos ovos, a média de diâmetro dos ovos aumentou para 1,90 $\pm 0,60 \mathrm{~mm}$, caracterizado pelo grande espaço vitelínico que persistiu até o desenvolvimento do embrião, duplo córion e os polos (animal e vegetal). A divisão celular iniciou-se aproximadamente dois minutos após a fertilização (AF), resultando em 2, 4, 8 (4 × 2 arranjo das células), 16 (4 x 4), 32 (4 x 8) e 64 ( 2 × 4 × 8) células. Adicionalmente, seguiram as fases de blástula e gástrula depois das divisões celulares. O fechamento do blastóporo ocorreu às 11 h 20 min AF; seguindo o desenvolvimento, os estágios de organogênese foram identificados e subdivididos,

${ }^{1}$ Universidade de São Paulo, Instituto de Biociências, Rua do Matão, Trav. 14, 321, 05508-090 São Paulo, SP, Brazil. honjijp@usp.br (RMH), ctolussi@usp.br (CET)phmello@usp.br (PHM), renatagm@ib.usp.br (RGM)

${ }^{2}$ Companhia Energética de São Paulo (CESP), Unidade de Hidrobiologia e Aquicultura, Rodovia dos Tamoios, km 38. 12260-000 São Paulo, SP, Brazil.danilo.caneppele@cesp.com.br (DC) 
respectivamente em: fase de divisão inicial e fase de divisão avançada. Na fase de divisão inicial, depois do estabelecimento do eixo do embrião, foi possível distinguir as regiões cefálica e caudal; os somitos e as vesículas ópticas se desenvolveram com aproximadamente $20 \mathrm{~h} \mathrm{AF}$. A eclosão total ocorreu com cerca de $54 \mathrm{~h} \mathrm{AF}$ e o comprimento médio foi de $4,30 \pm 0,70 \mathrm{~mm}$. A redução gradual do saco vitelínico foi observada durante os primeiros dois dias de desenvolvimento larval. A primeira alimentação ocorreu no final do segundo dia. Durante a fase larval, canibalismo, crescimento larval heterogêneo e fotofobia também foram observados. Estas informações serão importantes para aperfeiçoar o protocolo de reprodução artificial em $S$. parahybae em programas de reprodução controlada.

Key words: Artificial reproduction, Early development, Eggs, Larvae, Surubim do Paraíba.

\section{Introduction}

The teleost order Siluriformes, which includes the largest number of living teleost fish species, contains 3093 species popularly known as "catfish" (Ferraris, 2007). In this group the family Pimelodidae is a large and diversified family of freshwater catfishes (Burgess, 1989). The Neotropical catfish genus Steindachneridion within the order Siluriformes, family Pimelodidae (Garavello, 2005), has six species described: S. parahybae (Steindachner, 1877), S. amblyurum (Eigenmann \& Eigenmann, 1888), S. doceanum (Eigenmann \& Eigenmann, 1889), S. scriptum (Miranda Ribeiro, 1918), S. punctatum (Miranda Ribeiro, 1918), S. melanodermatum Garavello, 2005. Little is understood about the reproductive biology of this genus. This lack of knowledge is likely because the species within this genus have a naturally restricted environment and are relatively hard to collect, resulting in a limited number of Steindachneridion species available for biological studies (Garavello, 2005). Additionally, many of these species are at risk for extinction because of environmental disturbances that result in the reduction of their natural habitat (Honji et al., 2009).

The surubim do Paraíba, Steindachneridion parahybae (Fig. 1), is a medium-sized Neotropical catfish freshwater species endemic to the Paraíba do Sul River basin, which cross three Brazilian states (Rio de Janeiro, Minas Gerais, and São Paulo States), and is critically threatened (Caneppele et al., 2008; Honji et al., 2009; Polaz et al., 2011). The main threats to $S$. parahybae are the construction of dams, riparian habitat destruction, water pollution and fishing (Honji et al., 2009). Since 2003, CESP has supported researches on the biology of $S$. parahybae, including the maintenance of broodstocks and successful larval rearing, in order to ensure the conservation of this species. There have been no recent reports of this species in the southern rivers of the Paraíba do Sul River basin (São Paulo, 2008). However, S. parahybae was commonly captured in the commercial fisheries (around $1,000 \mathrm{~kg} /$ year) along the Paraíba do Sul River during the 1950s (Machado \& Abreu, 1952). Nowadays, this species is only captured in Paraíba do Sul River in Rio de Janeiro State; and Pomba and Paraibuna Rivers in Minas Gerais State, as observed in professional fishing data (Polaz et al., 2011).

There are few studies on the reproductive biology of Brazilian Pimelodidae, although, it has been observed a number of descriptions of the spawning strategies and larvae development of some Pimelodidae species as:
Pseudoplatystoma fasciatum (Leonardo et al., 2004), Pseudoplatystoma corruscans (Campos, 2005), Rhamdia quelen (Baldisseroto \& Neto, 2005), Pimelodus maculatus (Buzollo et al., 2011), Pauliceia luetkeni, and Iheringichthys labrosus (Nakatani et al., 2001). Furthermore, reproductive status of broodstock when reared under different rearing systems and hormonal treatment (hormone stimulation techniques to induce ovulation and spermiation) of Pimelodidae species were also described (Batlouni et al., 2006; Andrade et al., 2010; Romagosa, 2010). On the other hand, considering the number of species and their threatened situation, similar to the genus Steindachneridion, there is little descriptive information on reproduction and early development stages of this genus, such as: $S$. melanodermatum (Ludwig et al., 2005; Feiden et al., 2006); $S$. scripta (Adamante et al., 2007; Zaniboni-Filho et al., 2008), and no information is available to $S$. parahybae. According

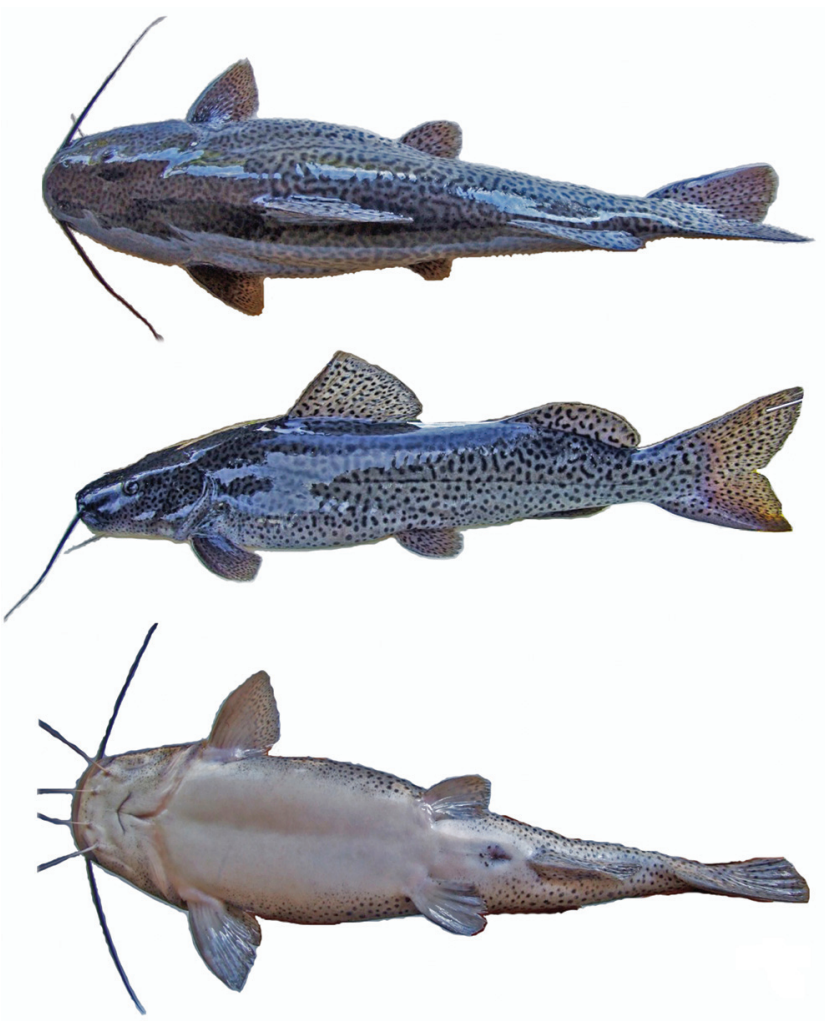

Fig. 1. Dorsal, lateral and ventral views of Steindachneridion parahybae. Broodstock female, $520 \mathrm{~mm}$ total length, Paraíba do Sul River basin, Paraibuna, São Paulo State, Brazil. 
to Feiden et al. (2006), it is very important to study embryos and larvae development, within two main goals, conservation and commercial fish farming.

Studies on the early development of fish not only yield information on spawning locations and the development features of the different species, but also allow comparisons between normal and altered development patterns (Meijide \& Guerrero, 2000), and/or environmental influences (i.e., temperature and photoperiod), on the mechanisms of development during early-life stages (Feiden et al., 2006; Schütz et al., 2008; Zaniboni-Filho et al., 2008). These data will be also of great use in determining the biological changes when the wild broodstocks are transferred to captivity; therefore, they have a practical application in fish farming and fisheries biology (Meijide \& Guerrero, 2000; Wikelski \& Cooke, 2006). Furthermore, these studies are even essential in the Paraíba do Sul River basin, considering that the rivers of this basin receive a large discharge of domestic and industrial pollution (Polaz et al., 2011).

Many teleost species have reproductive dysfunction in captivity (Mylonas et al., 2010), including S. parahybae, which results in problems with the production of fingerlings of native species in Brazil. Therefore, fish conservationists must investigate embryonic and larval development to find ideal conditions for the production of fingerlings and to obtain higher rates of survival in captivity (Honji et al., 2011). Furthermore, the information garnered from field investigation is essential to ensure the success of conservation programs (Wikelski \& Cooke, 2006). Similarly, conservation efforts in the field could be more successful if corroborated by captivity studies. Therefore, study of the development of various fish species in captivity is one of the first steps in helping conservation biologists rescue endangered species, such as, many Pimelodidae: Steindachneridion parahybae (Honji, 2011), S. melanodermatum (Feiden et al., 2006), S. scripta (Adamante et al., 2007), S. scriptum (Schütz et al., 2008), Rhamdia quelen (Soso et al., 2007), Pseudoplatystoma corruscans, and Lophiosilurus alexandri (Santos \& Luz, 2009).

Captivity studies of fish are also applicable to aquaculture. The elucidation of feeding behavior, prey preferences, the ecology of the larvae of cultured fishes, and the marking of developmental time-points like yolk sack absorption and mouth opening (which varies among species) will determine the requirements for exogenous food during larval growth (Appelbaum \& Mcgeer, 1998). For example, the high rate of cannibalism observed in cultured fishes is frequently due to inadequate larval food and an improper feeding regime, demonstrating the importance of studying larval development (Appelbaum \& McGeer, 1998).

The first step in the study of any species is to obtain knowledge of the embryonic and larval stages. This knowledge allows for morphological and physiological understanding of the species and helps to control the period of the larvae vulnerability. With information about appearance of organs, their functionality and their exact time of emergence, it is possible to establish management protocols and specific food recommendations for this critical phase. This information is even more important in this study, because is the first characterize $S$. parahybae development, considering the status of conservation, i.e., listed in the Brazilian red list (Caneppele et al., 2009), and regionally extinct in the São Paulo State (São Paulo, 2008; Honji et al., 2009).

The aim of this study was to describe the morphological events related to embryogenesis and larval ontogenesis of $S$. parahybae. We induced spawning in captive S. parahybae and followed progeny development from oocyte activation until the beginning of the juvenile period. This study is important in understanding the early development of genus Steindachneridion in order to contribute to the conservation of this species.

\section{Material and Methods}

This study was performed at the Hydrobiology and Aquaculture Unit of the Energetic Company of São Paulo State (CESP) located in Paraibuna city, São Paulo State, Brazil $\left(23^{\circ} 41^{\prime} 39^{\prime \prime} \mathrm{S} 45^{\circ} 60^{\prime} 42^{\prime \prime} \mathrm{W}\right)$. This study is also associated with the conservation program of endangered species of the Paraíba do Sul Basin, undertaken by CESP (Caneppele et al., 2009). During 2003, fifteen $S$. parahybae specimens were caught in the Paraíba do Sul River, near the town of Rio das Flores in the State of Rio de Janeiro (22 $\left.13^{\prime} 54^{\prime \prime} \mathrm{S} 43^{\circ} 25^{\prime} 15^{\prime \prime} \mathrm{W}\right)$, and these individuals were brought to the CESP hatchery to induce spawning. Descriptions of the fishing gear, catch operations and induced spawning of this wild broodstock were followed in accordance with Caneppele et al. (2009).

\section{Broodstock selection, hormonal induction and spawning}

The reproductive period of $S$. parahybae at CESP Fish Farm was from late spring (November) until March, with a reproductive peak in December and January. Therefore, in December 2007 and January 2008, two artificial reproductions were performed using two females and two males in each experiment, that were selected on the basis of the typical morphological characteristics of sexual ripeness, according to the principles previously established for $S$. parahybae (Caneppele et al., 2009). Briefly, the females were selected by external characteristics of the hyperemic genital pore and swollen abdomen. Furthermore, a biopsy procedure was conducted, cannulating the gonoduct with a fine polyethylene tubing ( $5 \mathrm{~mm}$ diameter) attached to a plastic syringe through the gonad papilla. This procedure allowed us to collect several oocytes to better observe their size, appearance, and diameter homogeneity, which are important criteria used to assess the status of female broodstock for the hormonal induction (Harvey \& Carolsfeld, 1993). The features of oocytes' diameters and appearance were analyzed under a stereomicroscope (Leica S6D stereomicroscope), and some oocytes were fixed in Bouin's solution for 24 hours for routine histological techniques (described below). Males were chosen according to the color and running sperm when the abdominal 
region was gently massaged. The protocol for broodstock selection for artificial reproduction was previously described for the genus Steindachneridion (Ludwig et al., 2005; Adamante et al., 2007; Caneppele et al., 2009).

Animals were caught in ponds, transferred to the laboratory at the same moment, kept in 1,000 L tanks, and shortly after, induced to reproduce by combining carp pituitary extract (CPE; Fish Braz) and human Chorionic Gonadotropin (hCG; Pregnyl - Organon) in the same application. For the hormonal induction, the CPE protocol was performed according to methods previously described for S. parahybae (Caneppele et al., 2009). Two CPE doses $(0.6 \mathrm{mg}$ and $5.4 \mathrm{mg}$ of CPE per $\mathrm{kg}$ of body weight, diluted in $0.9 \%$ sodium chloride solution) were given to females with a 12 hour interval between doses. Males were given a single dose at the same time as the females' second dose; this dose contained $3 \mathrm{mg}$ of CPE per $\mathrm{kg}$ and was also diluted in $0.9 \%$ sodium chloride solution. A single dose of hCG application was given to both females and males at the same time as the second CPE application. The hCG concentration used was 2 IU per kg-1 for females and $1 \mathrm{IU}$ per kg-1 for males. The dosages used in this study and the broodstock's weight and length are displayed in Table 1.

After hormone induction, each couple was placed in a glass $\operatorname{tank}(1,000 \mathrm{~L})$ to facilitate the observation of their sexual behavior during spawning. The time necessary for gamete elimination, counted from the second hormone administration until spawning, was calculated as Unit Thermal Accumulated (UTA), or degree-hours. Therefore, the UTA is the sum of the water temperature per hour, from the second hormonal application until spawning (Weingartner \& Zaniboni-Filho, 2005). Subsequently, the gametes from males and females were stripped in plastic containers and the dry extrusion was carried out. The oocytes were weighed, kept in a bowl, the sperm were added and then the mixture was gently homogenized. Water was then added for hydration to allow fertilization (according to the protocol described by Caneppele et al., 2009). Furthermore, following the gametes extrusion, the broodstocks were transferred back into their original ponds ( $100 \%$ survival).

Six hours after the eggs were placed in the conical incubator, when the gastrula stage was well established, the fertility rate was calculated using the equation $\mathrm{F}=$ (number of fertilized eggs x 100) / number of total eggs (Vazzoler, 1981, 1996). This protocol is a routine adopted at CESP, where the fertilized eggs were distinguished from the unfertilized eggs according to the general aspect and color, considering that the unfertilized ones are opaque. We also measured the temperature and dissolved oxygen every hour (Horiba ModU10), and all recorded values were expressed as the mean \pm standard error of the mean $(\mathrm{M} \pm \mathrm{SEM})$.

\section{Water quality}

The water quality during the artificial reproduction and embryonic development is shown in Table 2. The average water temperature and dissolved oxygen concentration during the artificial hormonal reproduction (first and second doses), spawning season, and annual mean, respectively, were as follows: $23.75 \pm 0.75^{\circ} \mathrm{C}$ and $7.94 \pm 0.20 \mathrm{mg} / 1 ; 23.70 \pm 1.10^{\circ} \mathrm{C}$ and $7.67 \pm 1.03 \mathrm{mg} / 1 ; 24.13 \pm 0.47^{\circ} \mathrm{C}$ and $7.70 \pm 0.79 \mathrm{mg} / 1 ; 21.10$ $\pm 0.14^{\circ} \mathrm{C}$ and $7.58 \pm 0.36 \mathrm{mg} / \mathrm{l}$. Furthermore, during the ten first days of the embryonic/larval development the average water temperature and dissolved oxygen was: $22.40 \pm 0.27^{\circ} \mathrm{C}$ and $7.30 \pm 0.33 \mathrm{mg} / \mathrm{l}$.

\section{Characteristics of the freshly spawned egg and larval analysis}

The main morphological features of each developmental stage were described. The oocytes, eggs and larvae at each sampling, were measured using a Leica DM1000 microscope or Leica S6D stereomicroscope connected Leica DFC295 camera and using a computer image capture Leica Application Suite professional. Every ten minutes, fresh eggs samples were collected for analysis and a photographic record was taken until hatching. After hatching, larvae were sampled at every twenty four hours during the first ten days (at the same hour of day).

After hatching and the macroscopic observation of absorption of yolk sac, Astyanax altiparanae larvae (ad libitum) were offered during the first three days, followed by Prochilodus lineatus larvae until the $10^{\text {th }}$ day. At the same time when $P$. lineatus larvae were offered, inert feeding was also initiated, with a prepared food (commercial fish food $45 \%$ of crude protein; and milled fish in a $4: 1$ ratio). At the $10^{\text {th }}$ day of age the larvae were eating only this prepared food, without any other live prey. The developmental stage was established when more than $50 \%$ of the specimens were in the corresponding stage. This parameter was measured using five sub-samples of the same group.

Table 1. Steindachneridion parahybae reproduction at CESP Fish Farm in December/2007 and in January/2008. Data are presented as the mean \pm standard error.

\begin{tabular}{|c|c|c|c|c|c|c|c|}
\hline Animals & & $\mathrm{N}$ & Mean \pm SD & $\begin{array}{l}\mathrm{hCG} \\
(\mathrm{IU} / \mathrm{kg})\end{array}$ & First CPE dose (mg/kg) & $\begin{array}{c}\text { Second CPE } \\
\text { dose }(\mathrm{mg} / \mathrm{kg})\end{array}$ & $\begin{array}{c}\text { Eggs spawned } \\
\text { weight }(\mathrm{g})\end{array}$ \\
\hline Females & $\begin{array}{l}\text { Total weight }(\mathrm{g}) \\
\text { Total length }(\mathrm{cm})\end{array}$ & 4 & $\begin{array}{c}2025.00 \pm 319.83 \\
55.75 \pm 2.32\end{array}$ & 2 & 0.60 & 5.40 & $92.20 \pm 29.99$ \\
\hline Males & $\begin{array}{l}\text { Total weight }(\mathrm{g}) \\
\text { Total length }(\mathrm{cm})\end{array}$ & 4 & $\begin{array}{c}1675.00 \pm 209.66 \\
53.00 \pm 2.12\end{array}$ & 1 & - & 3.00 & \\
\hline $\begin{array}{l}\text { Interval between doses } \\
\text { Accumulated thermal unit (ATU) } \\
\text { Fertilization rate }\end{array}$ & & & & & $\begin{array}{c}12 \text { hours } \\
200-255(231 \pm 16.25) \\
69.50 \pm 10.20 \%\end{array}$ & & \\
\hline
\end{tabular}


Table 2. Water quality during the period of artificial reproduction at CESP Fish Farm. Data are presented as the mean \pm standard error.

\begin{tabular}{lcc}
\hline Period of artificial reproduction & $\begin{array}{c}\text { Water temperature } \\
\left({ }^{\circ} \mathrm{C}\right)\end{array}$ & $\begin{array}{c}\text { Dissolved oxygen } \\
(\mathrm{mg} / \mathrm{L})\end{array}$ \\
\hline First injection $(0.6 \mathrm{mg} \mathrm{CPE} / \mathrm{kg})$ & $23.75 \pm 0.75$ & $7.94 \pm 0.20$ \\
Second injection $(5.40 \mathrm{mg} \mathrm{CPE} / \mathrm{kg})$ & $23.70 \pm 1.10$ & $7.67 \pm 1.03$ \\
Spawning & $24.13 \pm 0.47$ & $7.70 \pm 0.79$ \\
Ten first days & $22.40 \pm 0.27$ & $7.30 \pm 0.33$ \\
Annual mean & $21.10 \pm 0.14$ & $7.58 \pm 0.36$ \\
\hline
\end{tabular}

We also collected samples at each major macroscopic ontogenetic change, and fixed some eggs and larvae in Bouin's solution for 20-24 hours (depending on the samples size) for routine histological techniques. Briefly, samples were dehydrated through an ascending series of increasing concentrations of ethanol, cleared in dimethylbenzene (xylene), and embedded in Paraplast (Erv-Plast; Erviegas Instrumental Cirúrgico, São Paulo, Brazil), and $5 \mu \mathrm{m}$ thick sections were stained with hematoxylin-eosin (Behmer et al., 1976). The slides were examined, and imaged using the Leica microscope and camera.

All eggs and larvae were fixed according to the institutional animal care protocols and approval (Protocol: 072/2008). Histological slices are preserved in the collection of the Laboratório de Metabolismo e Reprodução de Organismos Aquáticos (LAMEROA), Instituto de Biociências da Universidade de São Paulo.

\section{Terminology for embryonic development}

The nomenclature describing embryonic development and the early larval stages can sometimes be confusing because of the variety of terms used by different authors. In this study, we identified the embryonic and larval development stages according to the descriptions established for other Siluriformes studied so far (Cardoso et al., 1995; Buzollo et al., 2011) and also by Nakatani et al. (2001) and Richards (2006).

\section{Results}

\section{Broodstock selection, hormonal induction and spawning}

In the present study, all broodstocks (100\% survival) induced to spawning with this specific protocol responded positively to the artificial reproduction, and have external fertilization and produce pelagic eggs.

The spawning (by dry method) occurred within 200-255 $(231 \pm 16.25) \mathrm{ATU}$ (about $24^{\circ} \mathrm{C}$ ), with $92.20 \pm 29.99 \mathrm{~g}$ of eggs spawned (weight), and the fertilization rate was about $69.50 \pm$ $10.20 \%$ (Table 1). Additionally, we will describe the stages of embryogenesis when the eggs were incubated at a temperature of $23.75 \pm 0.75^{\circ} \mathrm{C}$.

\section{Characteristics of the freshly spawned egg and larval analysis \\ The following embryonic and larval development stages were established:}

Egg stage: the period from fertilization until hatching. In this stage, an egg consists of a chorion, perivitelinic space and the embryo with a yolk sac observed in the center.

Larval stage with yolk sac: This stage includes the time from hatching until the start of the exogenous feeding. The duration of this stage varies widely among fish species, which depends on the water temperature.

Larval stage - exogenous feeding: This stage includes the start of exogenous feeding and can last for a few days to months (depending on the temperature and species). In this study, the duration of this stage was established as ten days after the start of exogenous feeding.

\section{Egg stage}

Following spawning and fertilization until hatching period, we observed different stages of development, as follows: zygote, cleavage, including the morula phase, blastula, gastrula, organogenesis, and hatching, with particular features for $S$. parahybae embryos and larvae. Additionally, heterogeneity was observed during the embryo development, i.e., embryos at different embryonic stages were observed at the same moment, and due to this heterogeneity of development, the different stages of development were characterized when $50 \%$ of the eggs/embryos/larvae were in this specific stage. The time after fertilization (AF) is reported in parentheses.

Zygote stage. Initially, before hydration, it was possible to visualize that the eggs were yellow, nonadhesive, and ovoid in shape with an average diameter of $1.10 \pm 0.10 \mathrm{~mm}$ (Fig. 2a). After fertilization and hydration of eggs, easily evident (within 10-30 min AF), fertilization activates cytoplasmatic movements (cytoplasm streams towards the animal pole, where the nucleus is positioned, to form a prominent layer of cytoplasm known as blastodisc), and the average diameter of eggs increased to about $1.90 \pm 0.60 \mathrm{~mm}$ (Fig. 2b), characterized by a large perivitelline space (Fig. 2b) that persisted up to embryo development, the double chorion, and the poles (animal and vegetative). The yolk was concentrated in the vegetative pole, while the cytoplasm, nucleus and organelles were distributed over the animal pole (Fig. 2b).

Cleavage stage. The cleavage was typically characterized by creating a cellular region above the yolk sac, which was firstly divided in the blastodisc (the first cleavage, $1 \mathrm{~h} 20$ min AF), dividing this blastodisc into two blastomeres of equal size (embryonic cells, Fig. 2c). Second and third cleavages occurred, giving rise to four blastomeres (in a $2 \mathrm{x}$ 2 arrangement of cells, $1 \mathrm{~h} 40 \mathrm{~min}$ AF, Fig. 2d), and eight blastomeres (in a $2 \times 4$ arrangement of cells, 1 h $50 \mathrm{~min} \mathrm{AF}$, Fig. 2e). Following the cleavage (fourth and fifth cleavages), respectively, sixteen (in a $4 \times 4$ arrangement of cells, $2 \mathrm{~h} \mathrm{AF}$, Fig. 2f) and thirty-two blastomeres (in a $8 \times 4$ arrangement of cells, $2 \mathrm{~h} 10 \mathrm{~min}$ AF, Fig. 2g) were lying in only one layer, and possibly curved on the yolk sac surface. The sixth cleavage or sixty-four blastomeres (in a $2 \times 4 \times 8$ arrangement of cells, $2 \mathrm{~h} 40$ min AF, Fig. 2h) was still easily evident for observation; 

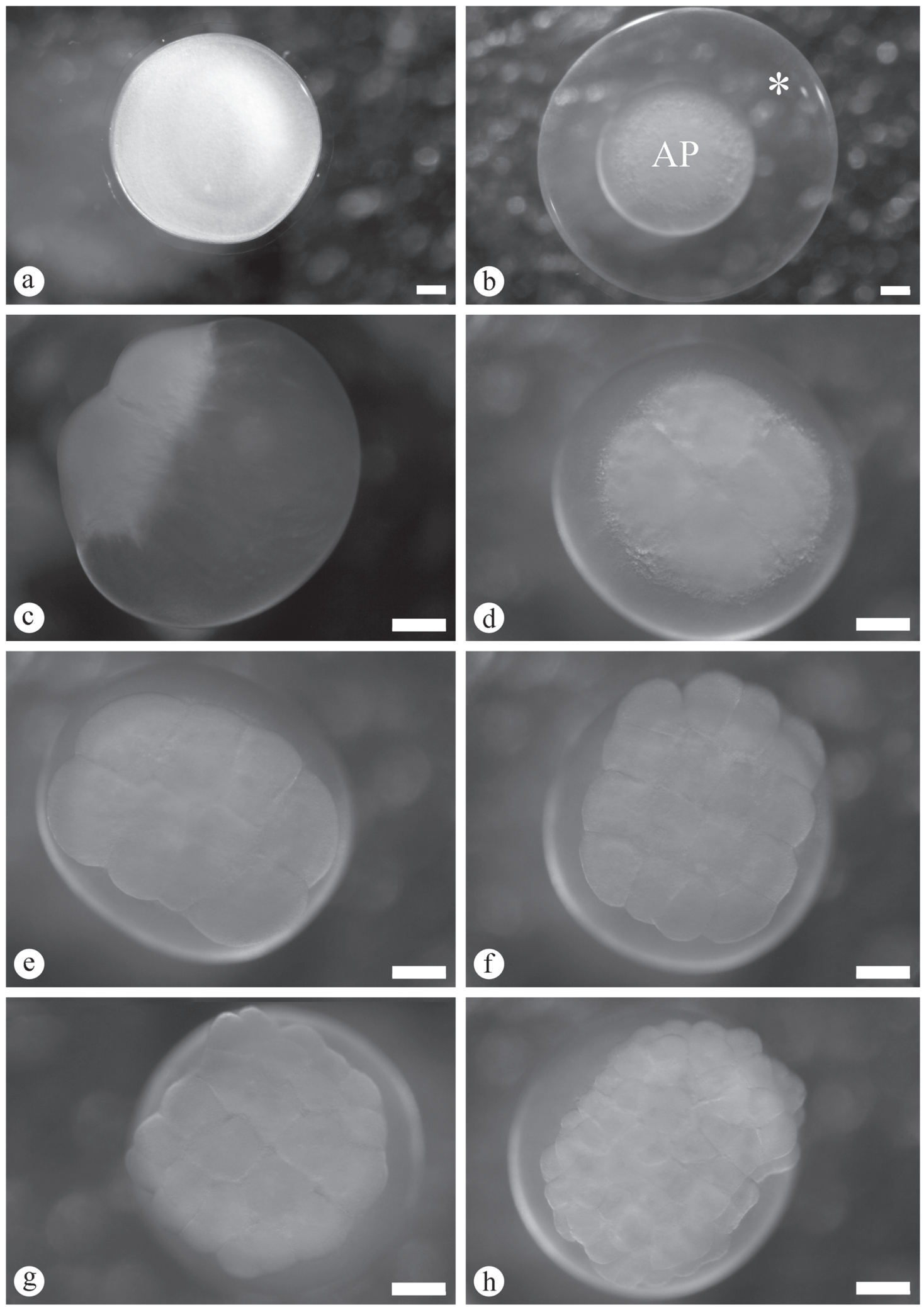

Fig. 2. Macroscopic aspects of embryonic development of Steindachneridion parahybae. a) oocyte extruded (just after spawning, and before fertilization and hydration) $-1.10 \pm 0.10 \mathrm{~mm}$; b) egg hydrated soon after fertilization (time zero AF) - 1.90 $\pm 0.60 \mathrm{~mm}$; c) two blastomeres ( $1 \mathrm{~h} 20 \mathrm{~min} \mathrm{AF}$ ); d) four blastomeres ( $1 \mathrm{~h} 40 \mathrm{~min} \mathrm{AF}) ; \mathbf{e}$ ) eight blastomeres ( $1 \mathrm{~h} 50 \mathrm{~min} \mathrm{AF}) ; \mathbf{f})$ sixteen blastomeres ( 2 h AF); g) thirty-two blastomeres ( 2 h 10 min AF); h) sixty-four blastomeres ( 2 h 40 min $\mathrm{AF})$. (*): perivitelinic space; (AP): animal pole. Bars: (a-b) $0.2 \mathrm{~mm}$; (c-h) $0.3 \mathrm{~mm}$. 
however some blastomeres completely covered others. Beyond the sixth cleavage, the number of small cells became increasingly higher and it was more difficult to discern any stereotypical arrangement of the blastomeres, besides; the cell cycles begin to lose synchrony and any patterns of cleavage plan.

The morula stage was characterized by successive cells divisions (more than sixty-four blastomeres) and arranged in a "half-berry"-like shape; the blastula stage was identified when the periblast and blastoderm region or embryonic cells became clear, and the animal pole presented a cup-like shape (without identification of embryonic cells boundaries) up to the beginning of the cell movement; when it began to characterize the gastrula stage, i.e., in this stage it was observed the occurrence of morphogenetic movement, named epiboly, which resulted in a rearrangement of the blastoderm relative to the yolk mass, and ultimately forms the germinative follicles and establishes the embryonic axis. The morphogenetic movement was divided in three steps: epiboly of $25 \%$ (Fig. 3a), epiboly of 50\% (Fig. 3b), and epiboly of $90 \%$ (Fig. 3c); and subsequently, the final gastrula stage, and blastopore closure (Fig. 3d). The morula stage occurred between $2 \mathrm{~h} 50 \mathrm{~min}$ and $11 \mathrm{~h} 20 \mathrm{~min}$ AF.

Following the development, the next stage identified was the organogenesis stage (Figs. 3e, f, g, h; 4a), which was subdivided respectively in: early segmentation phase and late segmentation phase (between: $14 \mathrm{~h} 25 \mathrm{~min}$ and $25 \mathrm{~h} \mathrm{AF}$ ). In the early segmentation phase, subsequently of the establishment the embryonic axis, it was possible to distinguish between the cephalic and caudal regions (14 h 25 min AF, Fig. 3f), where the tail was short and attached to the yolk mass, and along this axis, non-pigmented regions were observed; the optic vesicle was present (Fig. 3g); and the somites, that have a mesoderm origin and will give rise to the muscle, was also identified (Figs. 3g, h); this subdivision ended, when the tail detached and embryo started growing (Fig. 4a). Therefore, the late segmentation phase was characterized by the presence of the tail well extended and free from the yolk sac ( $25 \mathrm{~h} \mathrm{AF}$, Fig. 4a), many somites, optic vesicle well developed, and embryo growth. Additionally, during the late segmentation phase and before hatching, the embryo showed conspicuous muscular contraction.

Hatching stage (Fig. 4b). Vigorous muscular twitches of the enclosed embryo were important to break the chorion, which was softened and slimed now, and finally this movement resulted in the tearing of the chorion, and fry release (hatching start). Total hatching occurred at $54 \mathrm{~h} \mathrm{AF}$, and the average length was $4.30 \pm 0.70 \mathrm{~mm}$; thus the larval stage began.

\section{Larval stage with yolk sac and larval stage - exogenous feeding}

Day 1 (average length $4.50 \pm 0.80 \mathrm{~mm}$ ). After hatching $(\mathrm{AH})$, the larvae were still translucent, and the body was non- pigmented (Fig. 4c). Following the growth (23 h AH), we observed a slight reduction in the yolk sac (Fig. 4c), the early formation of barbells, and the mouth was not completely formed yet (not functional).

Day 2 (average length $4.60 \pm 1.20 \mathrm{~mm}$ ). A reduction in the yolk sac was observed, and the barbells were more visible ( $38 \mathrm{~h} 30$ min) (Fig. 4d). Gill development was observed, and in some larvae, but not all, the mouth and jaws were formed and mobile (40 $\mathrm{h}$ AH) (Fig. 4d). Approximately $50 \mathrm{hAH}$, exogenous food composed of 'lambari' (A. altiparanae) larvae was offered (Fig. 4e), and it was observed predation of 'lambari' by $S$. parahybae larvae. At that point, most $S$. parahybae larvae had open mouths, eyes with pigmented retinas, and still a smaller yolk sac.

Day 3 (average length $5.40 \pm \mathbf{2 . 1 0} \mathbf{~ m m}$ ). Exogenous feeding started by this time, therefore, there was a period of combined endogenous and exogenous food supply. Following the growth, about 60-70 h AH, we observed that the S. parahybae larvae were completely full of exogenous food (Fig. 4f). We could no longer detect the yolk sac by histological analysis, and the barbells were completely formed and well developed (Fig. 4e), as well as the caudal and anal fins, while dorsal and pectoral fins were still in the first steps of development. At this time (about 60-70 h AH), we also observed some cannibalism among the $S$. parahybae larvae (Figs. 5a, b).

Days 4 to 10. At approximately $80 \mathrm{~h} \mathrm{AH,} \mathrm{'curimbatá'} \mathrm{(} P$. lineatus) larvae were offered, and we observed intense cannibalism. After $100 \mathrm{~h} 57 \mathrm{~min} \mathrm{AH}$, exogenous feeding was initiated with a prepared food (Fig. 5c, d). Even when 'curimbatá' larvae were offered with prepared food (mixture of commercial fish food and milled fish) (Fig. 5d), we observed cannibalism among $S$. parahybae larvae. However, some larvae fed on prepared food (Fig. 5c, d) while others fed on 'curimbatá' larvae (Fig. 5d), or both (Fig. 5d). We also observed that the S. parahybae larvae displayed photophobia.

After three months, S. parahybae juvenile were an average length of $11.00 \pm 2.20 \mathrm{~cm}$. The time scales of the major events in the early development of $S$. parahybae are shown in figure 6 .

\section{Histological analysis}

In the present study, the females presented vitellogenic oocytes with central or slightly eccentric nuclei (Fig. 7a) with small nucleoli. Furthermore, the follicular layers were developed and could be easily seen even at this level of analysis (Fig. 7a). After fertilization and egg activation $(0 \mathrm{~m} \mathrm{AF})$, it was possible to identify the perivitellinic space and the yolk granules (Fig. $7 \mathrm{~b})$. The final gastrula and blastopore closure (11 h $20 \mathrm{~min} \mathrm{AF})$ and the differentiation between the cranial and caudal regions was observed microscopically (Fig. 7c).

Day 1 (after hatching). In the cranial region, we could identify the head, attached to the yolk sac, and the neurocranium. In the caudal region, we could identify the embryonic tail (Fig. 7d). At $34 \mathrm{~h} \mathrm{AH}$, the main structures of the larvae head were identified: 

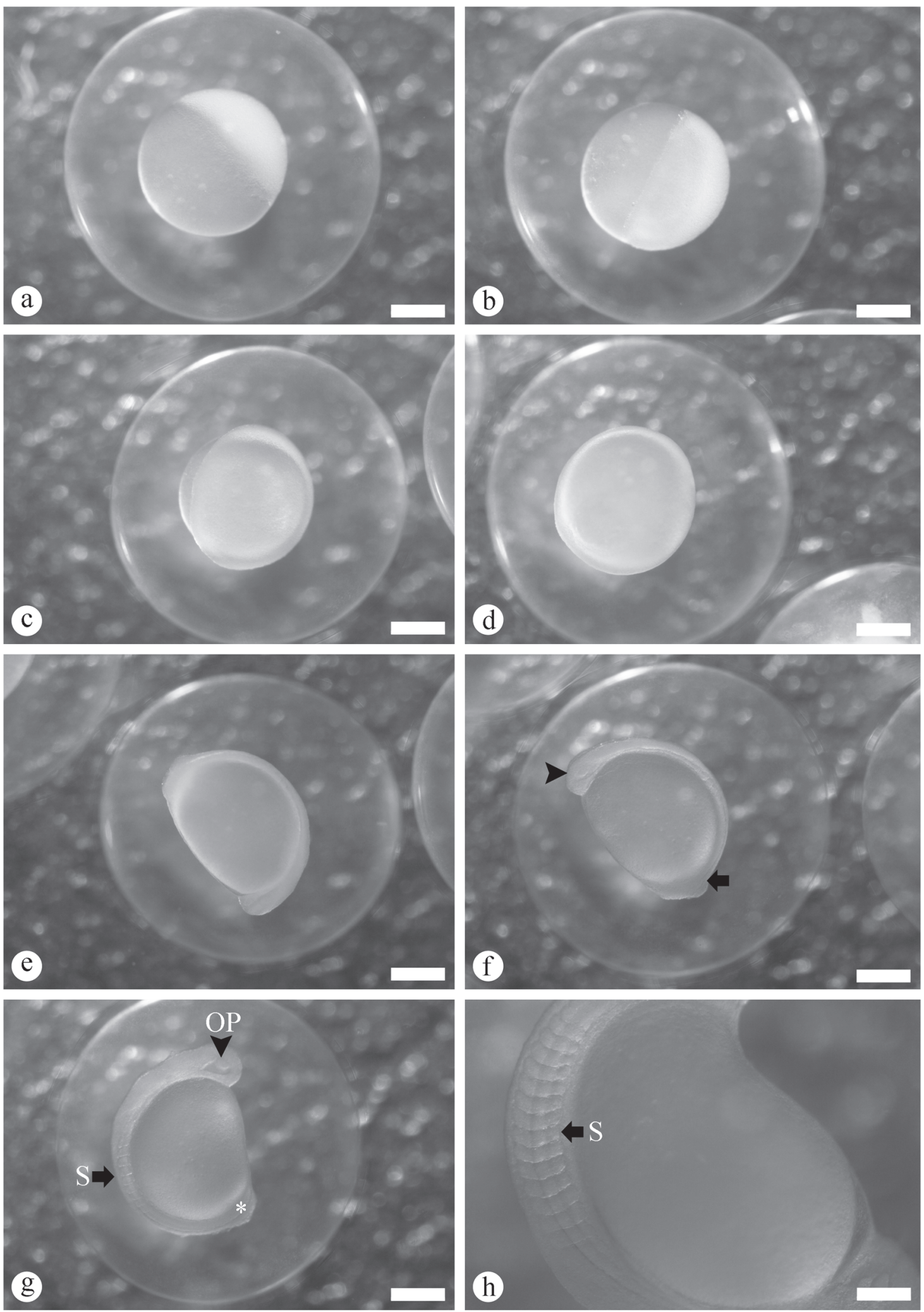

Fig. 3. Macroscopic aspects of embryonic and larval development of Steindachneridion parahybae. a-c) gastrula stage: a) epiboly of $25 \%$; b) epiboly of 50\%; c) epiboly of $90 \%$; d) final gastrula stage and blastopore closure (11 h 20 min AF); e-h) organogenesis stage: e) organogenesis and embryo growth (beginning of differentiation of embryonic layer); f) differentiation of embryonic layers, head (arrowhead) and tail (arrow) (14 h $25 \mathrm{~min} \mathrm{AF);} \mathrm{g)} \mathrm{distinguish} \mathrm{between} \mathrm{the} \mathrm{cephalic} \mathrm{(arrowhead)} \mathrm{and} \mathrm{caudal}$ (asterisk) regions, somites (S), and optic vesicle (OP); h) Detail of somites development (S). Bars: (a-g) $0.3 \mathrm{~mm}$; (h) $0.2 \mathrm{~mm}$. 

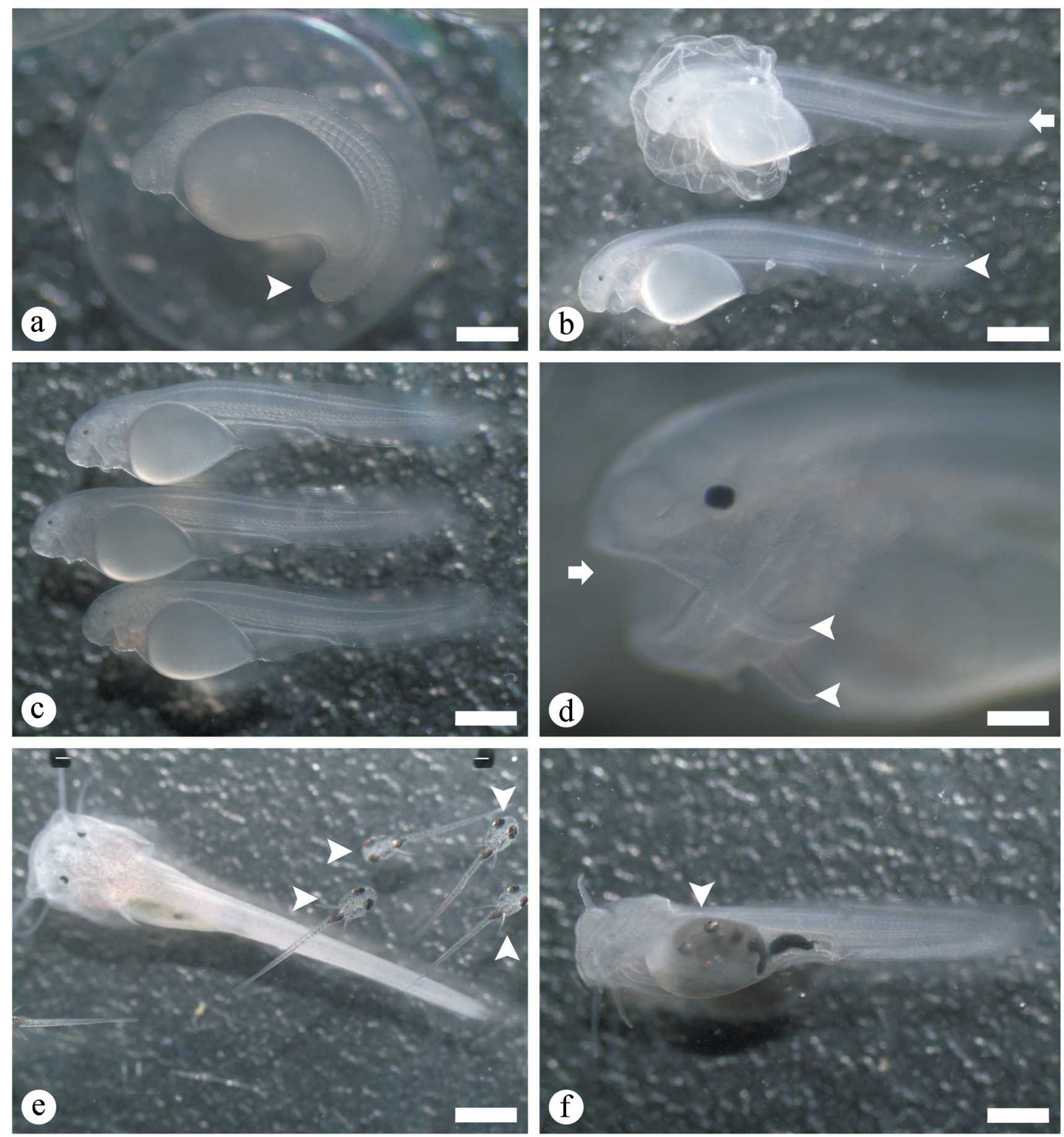

Fig. 4. Macroscopic aspects of larval development of Steindachneridion parahybae. a) complete development and the tail release (arrowhead) $(25 \mathrm{~h} \mathrm{AF})$; b) hatching (time zero AH) - $4.30 \pm 0.70 \mathrm{~mm}(54 \mathrm{~h})$. Hatched (arrowhead), and hatching (tearing of the chorion, and fry release; arrow); c) after hatching, the larvae were still translucent with a non-pigmented body; d) early formation of barbells (arrowhead) ( $38 \mathrm{~h} 30 \mathrm{~min} \mathrm{AH}$ ), and larvae with opened mouth (arrow) were observed although exogenous feeding have not been observed yet $(50 \mathrm{~h} \mathrm{AH})$; e) larvae fully developed (all structures) with barbells $(60 \mathrm{~h} \mathrm{AH})$, and exogenous feeding of $S$. parahybae with A. altiparanae larvae (arrowhead) (100 h $57 \mathrm{~min} \mathrm{AH})$; f) Detail of $S$. parahybae feeding at A. altiparanae larvae (arrowhead). Bars: (a) $0.3 \mathrm{~mm}$; (b-c) $0.9 \mathrm{~mm}$; (d) $0.2 \mathrm{~mm}$ (e-f) $0.8 \mathrm{~mm}$. 
eye, operculum, gill arches, and neurocranium (Fig. 7e). By the end of the second day, we could also identify the main features of the fish: head, tail, stomach, and others structures (Fig. 7f).

Early on the third day, we did not detect food in the larvae's stomach, despite the mouth being open (Fig. 7f). However, at $60 \mathrm{~h} \mathrm{AH}$, we could identify all features of the digestive system as shown in Figures $7 \mathrm{~g}, \mathrm{~h}, \mathrm{i}$ (mouth, esophagus, stomach, gut, and other), and some food in the digestive system ('lambari' or 'curimbatá' larvae).

\section{Discussion}

The water quality parameters analyzed in the present study were close to other research's which observed embryonic and larval development in other Neotropical species, mainly for the Siluriformes order, i.e., P. maculatus, R. quelen, P. fasciatum (Barcellos et al., 2004; Leonardo et al., 2004; Weingartner \& Zaniboni-Filho, 2004), and fish of the same genus of S. parahybae, as S. scripta (Adamante et al., 2007), S. scriptum (Schütz et al., 2008), and S. melanodermatum (Feiden et al., 2006).

The ATU values observed in this study were similar to those of other catfish species in the Pimelodidae family
(Weingartner \& Zaniboni-Filho, 2004; Campos, 2005), including other wild broodstocks of S. parahybae in captivity (Caneppele et al., 2009). Furthermore, the results of spawning induction experiments in $S$. parahybae from the wild broodstocks indicated that artificial reproduction is viable although the 'surubim do Paraíba' females release only a small amounts of eggs ( $\sim 53 \mathrm{~g}$ per females) (Caneppele et al., 2009). Using hormonal induction, we observed a slight increase in the amount of eggs released ( $\sim 92 \mathrm{~g}$ per females). Despite this slight increase, the amount of eggs that was released is below that observed in other Neotropical catfish, such as: R. quelen (Baldisserotto \& Neto, 2005), P. corruscans (Campos, 2005), S. melanodermatum (Ludwig et al., 2005), P. fasciatum (Leonardo et al., 2004).

The small quantity of eggs released during the artificial induction of $S$. parahybae can reflect the gonadossomatic index values, which increased during the final gonadal maturation and were similar after the hormonal induction of domesticated broodstock (Honji, 2011). Macroscopic and microscopic analysis of the gonads of S. parahybae may help explain the small quantity of eggs released. The pattern of oocyte development seems to be multiple-batch groupsynchronous (Rocha \& Rocha, 2006) during the reproductive
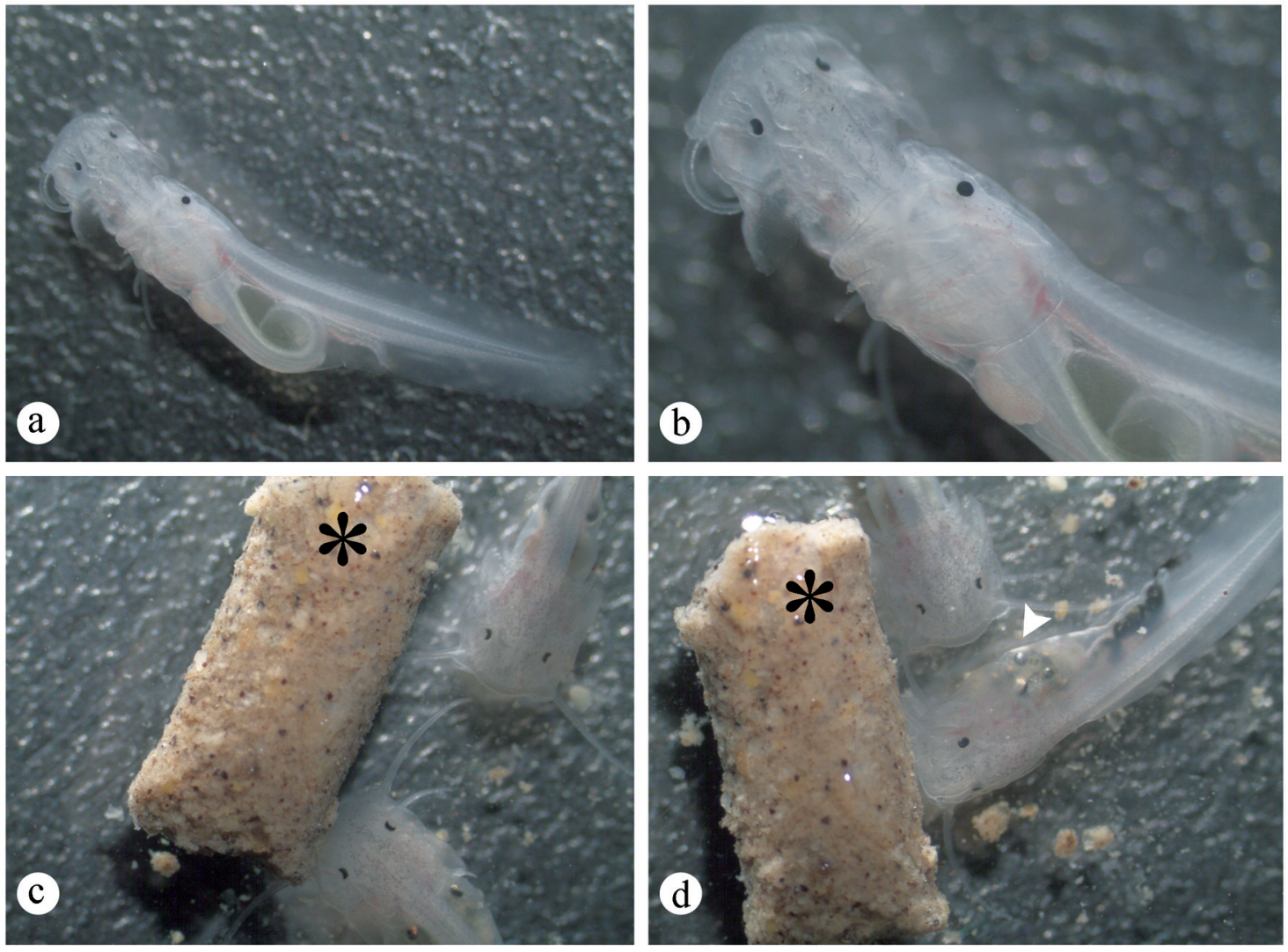

Fig. 5. Macroscopic aspects of larval development of Steindachneridion parahybae. a-b) cannibalism among the S. parahybae larvae; a) start of cannibalism among the $S$. parahybae larvae $(60 \mathrm{~h} \mathrm{AH})$; b) detail of cannibalism; c-d) exogenous feeding with prepared food; c) exogenous feeding was initiated with a prepared food (100 h $57 \mathrm{~min} \mathrm{AH}$ ); d) exogenous feeding of $S$. parahybae with Prochilodus lineatus larvae (arrowhead). (*) commercial fish food. Bars: (a, c, d) $0.8 \mathrm{~mm}$; (b) $0.4 \mathrm{~mm}$. 
season (Honji, 2011), a reproductive strategy also suggested for another Pimelodidae, P. corruscans (Godinho et al., 2007), a species commonly known as single spawners for most authors so far (Bazzoli, 2003; Godinho \& Godinho, 2003; Sato \& Godinho 2003; Campos, 2005).

Hand-stripping, followed by dry gamete fertilization is a good technique for S. parahybae (Caneppele et al., 2009), and the embryonic and larval development is similar to other Siluriformes species. The animal pole forms in S. parahybae at about $30 \mathrm{~min}$, which was similar to P. maculatus at $23.1^{\circ} \mathrm{C}$ (Luz et al., 2001). In P. maculatus the beginning of successive divisions in the animal pole was observed at $40 \mathrm{~min} \mathrm{AF} ; 32$ blastomere was observed at $1 \mathrm{~h} 40 \mathrm{~min} \mathrm{AF}$; and the blastopore closed was identified after 5 h 50 min AF (Luz et al., 2001). These results show that $P$. maculatus developed faster than $S$. parahybae. In P. corruscans the appearance of the animal pole and successive divisions began around $1 \mathrm{~h}$ and high blastula stage occurred within $2 \mathrm{~h} 50 \mathrm{~min} \mathrm{AF}$ (at 23.5-25.0 ${ }^{\circ} \mathrm{C}$ ) (Cardoso et al., 1995). The blastopore in S. parahybae closed at $11 \mathrm{~h} 20$ min AF, slightly later than that of P. corruscans, which occurred after $6 \mathrm{~h}$ AF under similar temperatures. Furthermore, the $P$. corruscans larvae at $25-26^{\circ} \mathrm{C}$ displayed blastopore closure at 6 h 30 min AF (Cardoso et al., 1995). Other Siluriformes species like Heterobranchus longifilis and Clarias gariepinus have an early embryonic development similar to S. parahybae, indicating that the development of surubim do Paraíba eggs generally follows that of other fish species, with small differences in time of development (Legendre \& Tcugcls, 1991).

At $11 \mathrm{~h} 20 \mathrm{~min}$ AF, it was possible to distinguish the cranial and caudal region in S. parahybae. However, in P. corruscans (Cardoso et al., 1995), P. maculatus (Luz et al., 2001), and Rhamdia hilarii (Godinho et al., 1978), this distinction occurred at $7 \mathrm{~h} 50 \mathrm{~min}, 10 \mathrm{~h} 50 \mathrm{~min}$, and $7 \mathrm{~h} 30 \mathrm{~min} A F$, respectively, under similar temperature conditions. Furthermore, the somites and optical vesicle of $P$. corruscans were visible during this period, but they were not visible in $S$. parahybae until $20 \mathrm{~h} 10 \mathrm{~min} \mathrm{AF}$. This result demonstrates the

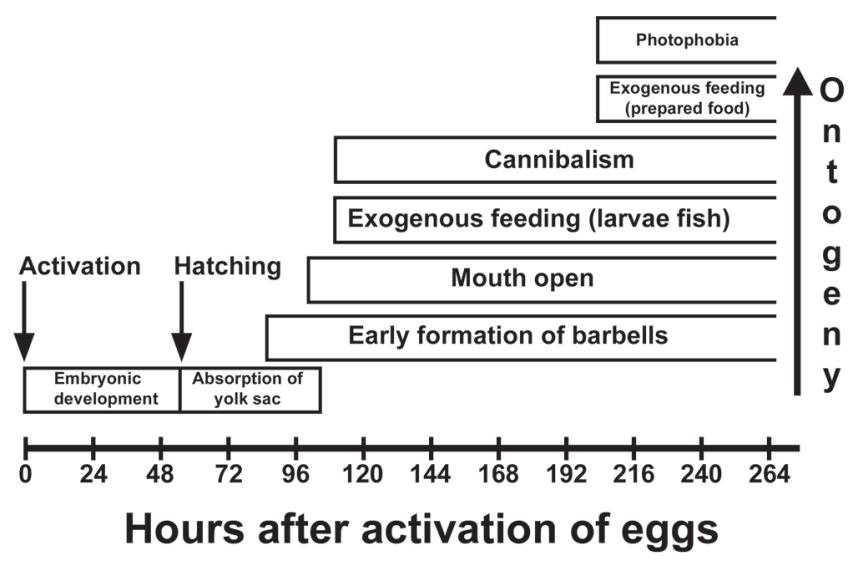

Fig. 6. Steindachneridion parahybae: major events during ontogeny of the surubim do Paraíba larvae. great difference in embryonic development between species, even those belonging to the same family.

The hatching period of S. parahybae $\left(54 \mathrm{~h}\right.$ at $\left.23^{\circ} \mathrm{C}\right)$ is later than other Siluriformes species, such as $P$. corruscans, which hatched $16 \mathrm{~h} \mathrm{AF}$ at a temperature of $24.5^{\circ} \mathrm{C}$ when the larvae were an average size of $2.51 \mathrm{~mm}$ (Nakatani et al., 2001). Similar times were observed in H. longifilis and C. gariepinus (Legendre \& Tcugcls, 1991). P. maculatus larvae hatched at $14 \mathrm{~h} 30 \mathrm{~min}$ $\mathrm{AF}$ at $25.5 \pm 0.3^{\circ} \mathrm{C}$ with the larvae measuring $2.56 \pm 0.13 \mathrm{~mm}$, or at $12 \mathrm{~h} \mathrm{AF}$ when reared at $27.6 \pm 1.4^{\circ} \mathrm{C}$ (Luz et al., 2001). Most fish species which migrate to reproduce have a rapid embryonic development, i.e., $22 \mathrm{~h}$ at $24^{\circ} \mathrm{C}$ for Prochilodus scrofa $(=P$. lineatus) (Cavicchioli \& Leonhardt, 1993$), 18 \mathrm{~h}$ at $25-26^{\circ} \mathrm{C}$ for Colossoma macropomum, and $22 \mathrm{~h}$ at $25-26^{\circ} \mathrm{C}$ for Piaractus mesopotamicus (Ribeiro et al., 1994). Interestingly, even though $S$. parahybae migrate to mate, their progeny do not develop quickly. The embryonic development time showed by $S$. parahybae is similar to or even faster than non-migratory fish species, such as Hoplias malabaricus and Parauchenipterus galeatus, which hatched $44 \mathrm{~h}$ at $24-26.5^{\circ} \mathrm{C}$ and $64 \mathrm{~h}$ at $27-28^{\circ} \mathrm{C}$ AF, respectively (Sanches et al., 1999, 2001). However it must be considered that the experimental temperature for $S$. parahybae in the present study was lower $\left(23^{\circ} \mathrm{C}\right)$ than most of the species above described, another reason for the slower development speed, since teleosts are ectothermic vertebrates.

During the larval development, adequate levels and intensity of light are required to optimize growth of many fish species (Boeuf \& Bail, 1999). The rapid growth of larvae during this period depends upon vision in order to find food, select prey, and avoid predators (Appelbaum \& Mcgeer, 1998; Boeuf \& Bail, 1999). In contrast, other species, including Siluriformes, such as, C. gariepinus (Appelbaum \& Mcgeer, 1998), P. maculatus (Luz et al., 2001), R. quelen (Boeuf \& Bail, 1999), Steindachneridion sp. (Feiden et al., 2005, 2006), S. scriptum (Schütz et al., 2008), the larvae can feed independent of the vision, because they show photophobia, having a better development when they are stored in dark or low intensity light (Appelbaum \& Mcgeer, 1998; Schütz et al., 2008). Furthermore, studies with Siluriformes species indicate that dark environments also reduce the stress and consequently improve larval development (Appelbaum \& Mcgeer, 1998; Feiden et al., 2005, 2006). Previous studies of S. parahybae larvae (Caneppele et al., 2009) and this study observe photophobia in $S$. parahybae larvae. Therefore, further studies of the influence of light on S. parahybae larval growth should be performed.

The main problem with the larviculture of Neotropical species in Brazilian Fish Farms (including S. parahybae) is the lack of knowledge about feeding during the larval development, mainly due to a lack of ecological, behavioral, and ontogenetic studies during this period. Much larvae mortality is directly related to inadequate feeding practices, which, in most cases, do not meet the real nutritional needs of larvae (Appelbaum \& Mcgeer, 1998). Although some techniques that use inert feed (starters) are well known and efficient for some species, many others species do not become accustomed to this management 

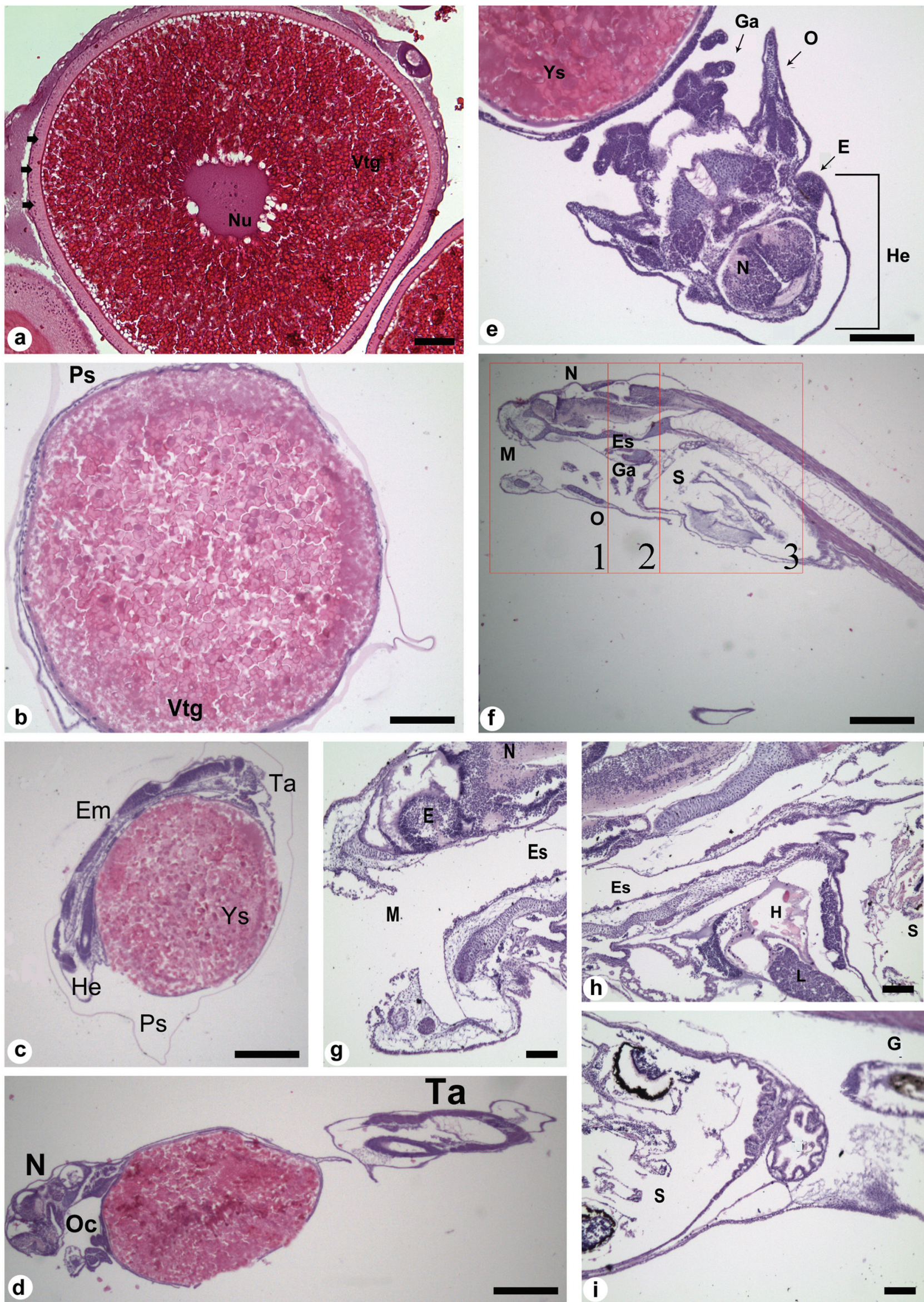
(Kamler, 1992). Thus, the employment of live food, as performed in the present study is recommended. We offered live food to S. parahybae larvae at first and transitioned to inert food on the eighth day. In our study, the 'surubim do Paraíba' larvae accepted this transition period, although we did observe some cannibalism during this period. Additionally, carnivorous fish larvae do not have a fully developed gastrointestinal tract and enzymatic activity when exogenous feeding begins (Dabrowski, 1984). Consequently, these animals are not able to digest inert food. This fact furthermore suggests that these larvae use the enzymes present in live food for digestion, in a process known as autolysis (Dabrowski, 1984).

Cannibalistic behavior, present when feeding practices are not adequate, is the main source of larvae mortality and production decrease in aquaculture. During rearing, which typically occurs in small ponds in larviculture, the chance of cannibalism is higher because of a higher density of larvae and a decreased chance of escape from predation (Smith \& Reay, 1991). Furthermore, heterogeneous growth in fish larvae is always observed in many teleost, such as seen in C. gariepinus (Hecht \& Pienaar, 1993) and in S. parahybae larvae (Caneppele et al., 2009) as also evidenced by the present study.

Cannibalism behavior was observed in 36 of 410 teleost families, with several species showing this behavior approximately $50 \mathrm{~h} \mathrm{AF}$ dependent upon temperature (Smith \& Reay, 1991; Nelson, 2006). To decrease the intensity of cannibalism, the following techniques can be applied: increase food availability, maintain shorter intervals of feeding, and

Fig. 7. (left page) Main features of oocytes and the phases of embryonic and larval development of Steindachneridion parahybae. a) Micrograph of oocyte in advanced maturation stage, showing the main characteristics of oocyte: follicular layers (arrow), yolk granules ( $\mathrm{VtG})$, and nucleus $(\mathrm{Nu})$. These oocytes were collected after cannulating the gonoduct with a fine polyethylene tubing attached to a plastic syringe; b) Egg hydrated, immediately after spawning and fertilization (time zero $\mathrm{AF}$ ): showing the yolk granules $(\mathrm{VtG})$ and perivitelline space (Ps); c) Final gastrula stage and blastopore closure followed by embryo (Em) differentiation of head (He), tail (Ta) and yolk sac (Ys) inside the perivitelline space (Ps); d) Hatching (time zero $\mathrm{AH}$ ): showing the neurocranium $(\mathrm{N})$, tail (Ta), and oral cavity (Oc); e) Detail of the head (He) - showing the main structures of He: neurocranium $(\mathrm{N})$, eyes $(\mathrm{E})$, operculum $(\mathrm{O})$, gill arches $(\mathrm{Ga})$, and yolk sac (Ys); f) Neurocranium $(\mathrm{N})$, opened mouth $(\mathrm{M})$, and the main structures of digestive and respiratory system: gill arches (Ga), stomach (S), esophagus (Es), and operculum (O). The number indicate the levels of histological section shown in detail in: $\mathrm{g}, \mathrm{h}$, and i; $\mathbf{g}, \mathbf{h}, \mathbf{i})$ Details of the digestive, sensorial, and respiratory system: eyes (E); esophagus (Es); gut (G); heart (H); liver (L); mouth (M); neurocranium (N); stomach (S). Hematoxylineosin staining. Bars: (a, b, e, g, h, i) $100 \mu \mathrm{m}$; (c, d, f) $400 \mu \mathrm{m}$. lower the stocking density (Howell et al., 1998). S. parahybae larvae showed a greater growth homogeneity and survival, with reduced cannibalism, when they were maintained in dark environment, at low stocking density, and with plenty of food available, ideally live food (fish prey) followed by inert food (Caneppele et al., 2009). These techniques, applied in the present study, were also observed in the genus Steindachneridion, such as S. melanodermatum (Ludwig et al., 2005; Feiden et al., 2006), S. scriptum (Schütz et al., 2008), and S. scripta (Adamante et al., 2007) when larvae were started with live food followed by inert food.

Many recent studies have shown the importance of conservation biology in the rescue of endangered wildlife (Wikelski \& Cooke, 2006). There are implications for the conservation of $S$. parahybae from the present study. The events in embryonic development and feeding behavior of fish larvae observed here allow for the development of strategies to obtain success in larval rearing. For example, a live food diet (forage larvae) in the early days of larval development and a gradual transition to an artificial diet will increase the survival of larvae. Since S. parahybae is endangered, this information is critical in contributing to the success of artificial reproduction programs (Honji et al., 2009). It is our recommendation that immediate action be taken in order to avoid the extinction of this species in the Paraiba do Sul River basin.

In conclusion, this study investigated the ontogeny and organogenesis of early development of $S$. parahybae. These data provide information that can be used to improve feeding protocols and to establish specific conservation management for this endangered catfish. Our data, together with the findings previously described by Caneppele et al. (2009), contribute to the recovery of this threatened species by giving biological tools to conservation biologists and aquatic physiologists to predict and solve future problems.

\section{Acknowledgements}

The authors would like to thank the local fishermen who helped to collect the wild females, Ms. Eduardo Sanches for providing the cannibalism pictures, CESP (Companhia Energética de São Paulo) for providing the Fish Farm facilities and FAPESP (2007/55949-7 and 2008/57687-0) for financial support.

\section{Literature Cited}

Adamante, W. B., M. Weingartner \& A. P. O. Nuñer. 2007. Feed transition in larval rearing of bocudo, Steindachneridion scripta (Pisces, Pimelodidae), using Artemia spp. Nauplli and artificial diet. Arquivo Brasileiro de Medicina Veterinária e Zootecnia, 59: 1294-1300.

Andrade, V. X. L., R. M. Honji \& E. Romagosa. 2010. Processo de maturação das gônadas de pintado (Pseudoplatystoma corruscans) alimentado com dois níveis proteicos e suplementados com óleo de milho. Arquivo Brasileiro de Medicina Veterinária e Zootecnia, 62: 332-342.

Appelbaum, S. \& J. C. McGeer. 1998. Effect of diet and light regime on growth and survival of African catfish (Clarias 
gariepinus) larvae and early juveniles. Aquaculture Research, 4: 157-164.

Baldisserotto, B. \& J. Radünz Neto. 2005. Jundiá (Rhamdia sp.). Pp. 303-325. In: Baldisserotto, B. \& L. C. Gomes. (Eds.). Espécies nativas para piscicultura no Brasil. Santa Maria, RS, UFSM, 305p.

Barcellos, L. J. G., L. C. Kreutz, R. M. Quevedo, I. Fioreze, L. Cericato, A. B. Soso, M. Fagundes, J. Conrad, R. K. Baldissera, A. Bruschi \& F. Ritter. 2004. Nursery rearing of jundiá, Rhamdia quelen (Quoy \& Gaimard) in cages: cage type, stocking density and stress response to confinement. Aquaculture, 232: 383-394.

Batlouni, S. R., E. Romagosa \& M. I. Borella. 2006. The reproductive of male catfish Pseudoplatystoma fasciatum (Teleostei, Pimelodidae) revealed by changes of the germinal epithelium an approach addressed to aquaculture. Animal Reproduction Science, 96: 116-132.

Bazzoli, N. 2003. Parâmetros reprodutivos de peixes de interesse commercial na região de Pirapora. Pp. 291-306. In: Godinho, H. P. \& A. L. Godinho (Eds.). Águas, peixes e pescadores do São Francisco das Minas Gerais. PUC Minas, Belo Horizonte, MG, 468p.

Behmer, O. A., E. M. C. Tolosa \& A. G. F. Neto. 1976. Manual de técnicas para histologia normal e patológica. EDART, São Paulo, 239p.

Boeuf, G. \& P. Y. Bail. 1999. Does light have an influence on fish growth? Aquaculture, 177: 129-152.

Burgess, W. E. 1989. An atlas of freshwater and marine catfishes. A preliminary survey of the Siluriformes. United States of America. 243p.

Buzollo, H., R. Veríssimo-Silveira, I. R. Oliveira-Almeida, J. S. Alexandre, H. T. Okuda \& A. Ninhaus-Silveira. 2011. Structural analysis of the Pimelodus maculatus (Lacépèle, 1803) embryogenesis (Siluriformes: Pimelodidae). Neotropical Ichthyology, 9: 601-616.

Campos, J. L. 2005. O cultivo do pintado, Pseudoplatystoma corruscans (Spix e Agassiz, 1829). Pp. 303-319. In: Baldisserotto, B. \& L. C. Gomes (Eds.). Espécies nativas para piscicultura no Brasil. Santa Maria, Rio Grande do Sul, Ed. UFSM, 470p.

Caneppele, D., P. Pompeu \& J. Garavello. 2008. Steindachneridion parahybae (Steindachner, 1876). Pp. 236238. In: Machado, A. B. M., G. M. Drummond \& A. P. Paglia (Eds.). Livro vermelho da fauna Brasileira ameaçada de extinção. Ministério do Meio Ambiente. Secretaria de Biodiversidade e Florestas. Departamento de Conservação da Biodiversidade. Brasília, DF, 908p.

Caneppele, D., R. M. Honji, A. W. S. Hilsdorf \& R. G. Moreira. 2009. Induced spawning of the endangered Neotropical species Steindachneridion parahybae (Siluriformes: Pimelodidae). Neotropical Ichthyology, 7: 759-762.

Cardoso, E. L., M. S. D. Alves \& R. M. A. Ferreira. 1995. Embryogenesis of the neotropical freshwater Siluriformes Pseudoplatystoma corruscans. Aquatic Living Resources, 8: 343-346.

Cavicchioli, M. \& J. H. Leonhardt. 1993. Estudo do desenvolvimento morfológico de larvas de curimbatá, Prochilodus scrofa (Steindachner, 1882), obtidas de reprodução induzida. Revista Unimar, 15: 109-124.

Dabrowski, K. 1984. The feeding of fish larvae: present "state of the art" and perspectives. Reproduction Nutrition Development, 24: 807-833.

Feiden, A., C. Hayashi, W. R. Boscolo \& A. Reidel. 2006. Desenvolvimento de larvas de Steindachneridion sp. em diferentes condições de refúgio e luminosidade. Pesquisa Agropecuária Brasília, 41: 133-137.

Feiden, A., C. Hayashi, W. R. Boscolo \& A. Signor. 2005. Desenvolvimento do surubim do Iguaçu (Steindachneridion sp., Garavello (1991)) (Siluroidei: Pimelodidae) em ambiente escuro durante a fase inicial, alimentado com diferentes dietas. Semina, Ciências Agrárias, 26: 109-116.

Ferraris Jr., C.J. 2007. Checklist of catfishes, recent and fossil (Osteichthyes: Siluriformes), and catalogue of siluriform primary types. Zootaxa, 1418: 1-628.

Garavello, J. C. 2005. Revision of genus Steindachneridion (Siluriformes: Pimelodidae). Neotropical Ichthyology, 3: 607-623.

Godinho, A. L., B. Kynard \& H. P. Godinho. 2007. Migration and spawning of female surubim (Pseudoplatystoma corruscans, Pimelodidae) in the São Francisco River, Brazil. Environmental Biology of Fishes, 80: 421-433.

Godinho, H. M., N. A. Fenerich \& M. Y. Narahara. 1978. Desenvolvimento embrionário e larval de Rhamdia hilarii (Valenciennes, 1840) (Siluriformes, Pimelodidae). Revista Brasileira de Biologia, 38: 151-156.

Godinho, A. L. \& H. P. Godinho. 2003. Breve visão do São Francisco. Pp. 15-24. In: Godinho, H. P. \& A. L. Godinho (Eds.). Águas, peixes e pescadores do São Francisco das Minas Gerais. PUC Minas, Belo Horizonte, MG, 468p.

Harvey, B. \& J. Carolsfeld. 1993. Induced breeding in tropical fish culture. International Development Research Centre. Ottawa, Canada. International Development Research Centre, 144p.

Hecht, T. \& A. G. Pienaar. 1993. A review of cannibalism and its implications in the fish larviculture. Journal of the World Aquaculture Society, 24: 246-261.

Honji, R. M. 2011. Controle do eixo hipotálamo-hipófise-gônadas do surubim do Paraíba Steindachneridion parahybae (Siluriformes: Pimelodidae) em relação ao ciclo reprodutivo e à reprodução induzida em cativeiro. Unpublished Ph.D Dissertation, Universidade de São Paulo. São Paulo, 300p.

Honji, R. M., D. Caneppele, A. W. S. Hilsdorf \& R. G. Moreira. 2009. Threatened fishes of the world: Steindachneridion parahybae (Steindachner, 1877) (Siluriformes: Pimelodidae). Environmental Biology of Fishes, 85: 207-208.

Honji, R. M., P. H. Mello, B. C. Araújo, J. A. Rodrigues-Filho, A. W. S. Hilsdorf \& R. G. Moreira. 2011. Influence of spawning procedure on gametes fertilization success in Salminus hilarii Valenciennes, 1850 (Teleostei: Characidae): implications for the conservation of this species. Neotropical Ichthyology, 9: 363-370.

Howell, B. R., O. J. Day, T. Ellis \& S. M. Baynes. 1998. Early life stages of farmed fish. Pp. 27-66. In: Black, K. D. \& A. D. Pickering (Eds.). Biology of farmed fish. Sheffield Academic Press, Sheffield, 429p.

Kamler, E. 1992. Early life history of fish: an energetic approach. Chapman \& Hall, Fish and Fisheries Series 4, London, 267p.

Legendre, M. \& G. G. Teugels. 1991. Développement et tolérance à la température des oeufs de Heterobranchus longifilis et comparaison des développements larvaires $H$. longifiis et de Clarias gariepinus (Teleostei, Clariidae). Aquatic Living Resources, 8: 227-240.

Leonardo, A. F. G., E. Romagosa, M. I. Borella \& S. R. Batlouni. 2004. Induced spawning of hatchery-raised Brazilian catfish, cachara Pseudoplatystoma fasciatum (Linnaeus, 1766). Aquaculture, 240: 451-461.

Ludwig, L. A. M., E. Gomes \& R. F. Artoni. 2005. Um método de reprodução induzida para o surubim Steindachneridion 
melanodermatum (Siluriformes: Pimelodidae) do Rio Iguaçu. Ciências Biológicas e da Saúde, 11:23-27.

Luz, R. K., D. A. Reynalte-Tataje, A. A. Ferreira \& E. ZaniboniFilho. 2001. Desenvolvimento embrionário e estágios larvais do mandi-amarelo Pimelodus maculatus. Boletim do Instituto de Pesca, 27: 49-55.

Machado, C. E. \& H. C. F. Abreu. 1952. Notas preliminares sobre a caça e a pesca no Estado de São Paulo. A pesca no Vale do Paraíba. Boletim Industrial Animal, 13: 145-160.

Meijide, F. J. \& G. A. Guerrero. 2000. Embryonic and larval development of a substrate-brooding cichlid Cichlasoma dimerus (Heckel, 1840) under laboratory conditions. Journal of Zoology, 252: 481-493.

Mylonas, C. C., A. Fostier \& S. Zanuy. 2010. Broodstock management and hormonal manipulations of fish reproduction. General and Comparative Endocrinology, 165: 516-534.

Nakatani, K., A. A. Agostinho, G. Baumgartner, A. Bialtzki, P. V. Sanches, M. C. Makrakis \& C. S. Pavanelli. 2001. Ovos e larvas de peixes de água doce: desenvolvimento e identificação. Maringá, Paraná, EDUEM, 378p.

Nelson, J. S. 2006. Fishes of the World. John Wiley and Sons, Inc. New York, 601p.

Polaz, C. N. M., Y. S. L. Bataus, A. Desbiez \& M. L. Reis. 2011. Caracterização da Bacia e Biologia das Espécies. Pp. 16-43. In: Plano de Ação Nacional para a Conservação das Espécies Aquáticas Ameaçadas de Extinção da Bacia do Rio Paraíba do Sul. Série Espécies Ameaçadas de nº 16. ICMbio. Brasilia, DF, $19 \mathrm{p}$.

Ribeiro, C. R., H. S. Leme dos Santos \& A. A. Bolzan. 1994. Estudo comparativo da embriogênese de peixes ósseos (pacu, Piaractus mesopotamicus; tambaqui Colossoma macropomum e hibrído tambacu). Revista Brasileira de Biologia, 55: 65-78.

Richards, W. J. 2006. Early stages of Atlantic Fishes. An identification guide for the Western Central North Atlantic. Taylor \& Francis, 2643p.

Rocha, M. J. \& E. Rocha. Morphofunctional aspects of reproduction from synchronous to asynchronous fishes- an overview. Pp. 571-624. In: Reinecke, M., G. Zaccone \& B. G. Kapoor (Eds.). Fish Endocrinology. Science Publishers, New Hampshire, 871p.

Romagosa, E. 2010. Reproductive status in females of the Brazilian catfish, Pseudoplatystoma fasciatum reared in cages. Journal of Applied Ichthyology, 26: 806-811.

Sanches, P. V., G. Baumgartner, A. Bialetzki, M. R. Suiberto, F. D. C. Gomes, K. Nakatani \& N. D. C. Barbosa. 2001. Caracterização do desenvolvimento inicial de Leporinus friderici (Osteichthyes, Anostomidae) da bacia do Rio Paraná, Brasil. Acta Scientiarum, 23: 382-389.

Sanches, P. V., K. Nakatani \& A. Bialetzki. 1999. Morphological description of the developmental stages of Parauchenipterus galeatus (Linnaeus, 1766) (Siluriformes, Auchenipteridae) on the floodplain of the upper Paraná River. Revista Brasileira de Biologia, 59: 429-438.

Santos, J. C. E. \& R. Luz. 2009. Effect of salinity and prey concentrations on Pseudoplatystoma corruscans, Prochilodus costatus and Lophiosilurus alexandri larviculture. Aquaculture, 289: 324-328.

São Paulo. 2008. Decreto Estadual n $53494-2008$ de 02 de outubro de 2008. Diário Oficial do Estado de São Paulo 118 (187). Secretaria do Meio Ambiente.

Sato Y. \& H. P. Godinho. 2003. Migratory fishes of the São Francisco River Pp: 195-231. In: Carolsfeld J., B. Harvey, C. Ross \& A.
Baer (Eds.). Migratory fishes of South America. World Fisheries Trust, Victoria, BC, Canada, 380p.

Schütz, J. H., M. Weingartner, E. Zaniboni-Filho \& A. P. O. Nuñer. 2008. Crescimento e sobrevivência de larvas de suruvi Steindachneridion scriptum nos primeiros dias de vida: influência de diferentes alimentos e fotoperíodos. Boletim do Instituto de Pesca, 34: 443-451.

Smith, C. \& P. Reay. 1991. Cannibalism in teleost fish. Reviews in Fish Biology and Fisheries, 1: 41-64.

Soso, A. B., L. J. G. Barcellos, M. J. Ranzani-Paiva, L. C. Kreutz, R. M. Quevedo, D. Anzileiro, M. Lima, L. B. Silva, F. Ritter, A. C. Bedin \& J. A. Finco. 2007. Chronic exposure to sublethal concentration of a glyphosate-based herbicide alters hormone profiles and affects reproduction of female jundiá (Rhamdia quelen). Environmental Toxicology and Pharmacology, 23: 308-313.

Vazzoler, A. E. A. M. 1981. Manual de métodos para estudos biológicos de populações de peixes: reprodução e crescimento. CNPq, Brasília, 108p.

Vazzoler, A. E. A. M. 1996. Biologia da reprodução de peixes teleósteos: teoria e prática. Maringá, EDUEM, 169p.

Weingartner, M. \& E. Zaniboni-Filho. 2004. Efeito de fatores abióticos na larvicultura de pintado amarelo Pimelodus maculatus (Lacépède, 1803): salinidade e cor de tanque. Acta Scientiarum, 26: 151-157.

Weingartner, M. \& E. Zaniboni-Filho. 2005. Dourado. Pp. 257281. In: Baldisseroto, B. \& L. C. Gomes (Eds.). Espécies nativas para piscicultura no Brasil. Santa Maria, Rio Grande do Sul. Ed.UFSM. 470p.

Wikelski, M. \& S. J. Cooke. 2006. Conservation physiology. Trends in Ecology \& Evolution, 21: 38-46.

Zaniboni-Filho, E., D. Reynalte-Tataje, A. P. O. Nuñer \& S. Meurer. 2008. Photoperiod influence on the cultivation of Steindachneridion scriptum (Pisces, Pimelodidae) juvenile. Brazilian Archives of Biology and Technology, 51: 555-561.

Submitted July 18, 2011

Accepted May 3, 2012

Published June 29, 2012 